\title{
A DISAGGREGATED, STRUCTURAL ANALYSIS \\ OF RETIREMENT BY RACE, DIFFICULTY \\ TO WORK AND HEALTH
}

Alan I. Gustman

Thomas L. Steinmeier

Working Paper No. 1585

\author{
NATIONAL BUREAU OF ECONOMIC RESEARCH \\ 1050 Massachusetts Avenue \\ Cambridge, MA 02138 \\ March 1985
}

The research reported herein was performed pursuant to a grant from the U.S. Department of Health and Human Services to the National Bureau of Economic Research. We would like to thank Olivia Mitchell for her comments. The research reported here is part of the NBER's research program in Labor Studies and project in Government Budget. Any opinions expressed are those of the authors and not those of the National Bureau of Economic Research or of any agency of the United States Government. 
NBER Working Paper \#1585

March 1985

\author{
A Disaggregated, Structural Analysis \\ of Retirement by Race, Difficulty \\ of Work and Health
}

\begin{abstract}
Intergroup differences in retirement rates by race, major occupation and health status are examined and allocated to differences in budget sets and indifference curve parameters. In addition, comparisons indicate that average retirement rates for groups may, at times, be misleading indicators of marginal responses to incentives. It is predicted that all groups will respond to the work incentives in the 1983 Social Security Amendments, even those ill health and difficult jobs, and the resulting increases in earnings are predicted to amount to from one sixth to over one half of the reduction in lifetime benefits created by the amendments.
\end{abstract}

\author{
Alan L. Gustman \\ Department of Economics \\ Dartmouth College \\ Hanover, NH 03755 \\ (603) 646-2641
}

Thomas L. Steinmeier Department of Economics Texas Tech University Lubbock, TX 79409 (806) $742-2203$ 


\section{Introduction}

There has been continuing interest is explaining intergroup differences in labor market outcomes between blacks and whites, between those in different occupations, and among other groupings. Given the recent advances in structura 1 estimation, it is now feasible to approach the analysis of intergroup differences in labor market outcomes in conventional economic terms, with some portion of the difference attributed to divergent market opportunities between the groups and another portion attributed to divergent preferences. A major purpose of this paper is to contribute to this approach to analyzing intergroup differences in labor market outcomes. Specificaliy, we will examine differences in retirement rates between blacks and whites and between those in more and less physically demanding jobs, and we will use maximum likelihood techniques to assess to what degree these differences are due to divergent market opportunities and to what degree they are due to divergent preferences among the groups.

There are two other motivations for this work. First, although there have been important advances in the specification and estimation of structural retirement models, these models have not been applied to analyze separately retirement behavior by older black males. " This is an important subject by itself, and one which we hope to shed some light on in this study. Secondly, Congress has demonstrated a concern that recent Social Security legislation which has extended the retirement age and reduced the Social security benefits for those who retire early will adversely affect those who because of poor health or physically demanding jobs are unable to adjust their dates of retirement. ${ }^{2}$ In order to suggest whether or not these concerns are warranted, the paper examines the differences in retirement behavior between those in more or less physically demanding jobs and analyzes the reasons for these differences 
and their relation to health status.

In the next section, descriptive statistics will be presented on the probabilities of ful1-time work, partial retirement, and ful1 retirement for groups of older workers disaggregated by race, occupation and health status. The following two sections describe a structural retirement model and present separate estimates of the model for blacks and whites in more and less physically demanding jobs. Section $V$ presents the results of simulations which assess how the explanation for differing retirement behavior among these various groups can be divided between divergent opportunity sets and divergent preferences. The next section, reflecting the Congressional concerns mentioned above, examines the likely effects of the 1983 Social Security amendments on individuals in poor health or holding the more physically demanding jobs. 3 A final section contains a summary, some caveats, and some indications of directions in which further work might be useful.

Among the findings of the study, three would appear to be of particular interest. First, the large differences in rates of full-time labor force participation observed between black and white males in their late fifties narrow considerably with age, both proportionately and in absolute terms, with the average rate of full-time work among older black males being only about two percentage points lower than the rate for older white males. Secondly, the two characteristics singled out by Congress, health status and occupation, do bear an important relation to retirement outcomes. Those in physically demanding jobs are 7 percentage points less likely to be working full-time than are those in less physically demanding jobs, and those in poor health are over thirty percentage points less likely to be working full-time than are those in good health. Finally, the 1983 social security amendments contain a number of provisions designed to increase work effort, especially by those over 65 . The analysis suggests that these incentives will produce little response among those 
under 65 but wi1l produce relatively larger responses among those between 65 and 69. Even those with long term health limitations would respond to incentives, although at half the rate of those in good health. In addition average rates of retirement do not always provide a reliable clue as to a group's marginal response. In particular, those in more physically demanding jobs appear to be about as responsive to incentives as those in less demanding jobs. These behavioral responses are large enough to amount to one sixth to over one half of the 11 to 14 percent reduction in social security benefits received over the lifetime which would result from 1983 Social Security amendments if there were no behavioral adjustments.

\section{Descriptive Statistics}

This section presents some basic descriptive statistics relating to the probability that an individual will be working full-time, the probability that he will be partially retired, and the probability that he will be fully retired. Let these three probabilities be denoted as $\mathrm{P}_{\mathrm{a}}$, $\mathrm{p}_{\mathrm{a}}$, and $\mathrm{P}_{\mathrm{a}}^{r}$ respectively, where a indicates the age of the individual. These retirement probabilities are in turn calculated from a weighted average of the corresponding probabilities for the eight groups of concern to us in this study, categorized by race, physical difficulty of work, and health. Thus for retirement status s we have:

$$
P^{S}=\Sigma_{i} \Sigma_{j} \Sigma_{k} P_{i j k}^{S} Q_{i j k}^{S}
$$

where $P_{i j k}^{S}$ is the probability of observing outcome $s$ for those in race $i$, with difficulty of work $j$, and with level of health $k$, and where for notational convenience the age subscript has been suppressed. $Q_{i j k}^{S}$ is the corresponding weight in the population for that group. 
Probabilities of falling into one of the three retirement categories are presented in Table 1 for various groups, as calculated from the Retirement History Survey (RHS). ${ }^{4}$ The measure of retirement used in this study is the individual's self-reported retirement status. ${ }^{5}$ jobs classified as more physically demanding (MPD) include craftsmen, foremen and kindred workers, operatives and laborers, while jobs classified as less physically demanding (LPD) include professionals, managers, and clerical, sales and service workers. Poor health is indicated by an individual's self-reported indication that for a prolonged period of time (at least one year) he has experienced a health problem that limits his ability to work. ${ }^{6}$ Alternative health measures which have been suggested, such as subsequent mortality (Parsons 1982), introduce other errors, and the direct use of medical data rather than self-reported health status both requires some procedure for matching health problems with the requirements of particular jobs and in addition would preclude the use of longitudinal surveys such as the RHS, surveys which contain other necessary information for analyzing retirement. 7 The probabilities presented in this table are based on a set of data which, after eliminating the self-employed, pools all responses for males in the RHS, not distinguishing either on the basis of the individual's age in the initial survey year, 1969, or on the basis of date of the survey wave.

The first panel of the table reports the aggregate retirement rates for the RHS, along with a breakdown by narrower age categories. The rapid decline in full-time work and the corresponding increase in full retirement during the 6070 year age range are both readily apparent from these data. Even by age 65 , the majority of individuals have stopped working full-time and have retired. The importance of partial retirement, especially after age 65 , is also evident. In fact, after age 65 there are more individuals who are partially retired than there are working fult-time. 
The second through fourth panels present three sets of differences between contrasting groups. Black-white differentials in retirement rates are summarized in the second panel, and these figures reveal an interesting finding. Although there are clear indications of the substantial differences in nonparticipation rates between black and white males in younger age groups, differences which have been emphasized by other authors (eg., see Parsons, 1980), the black-white differences in rates of full-time participation decline with age, both absolutely and as a proportion of the level of full-time participation observed for the sample. Overall, blacks in this survey were two percent less likely than whites to be working full-time, and correspondingly more likely to be fully retired or partially retired.

The importance for retirement outcomes of the two characteristics singled out by Congress, difficulty of work and health status, are readily apparent in the third and fourth panels of the table. 8 Those in demanding jobs are 7.0 percentage points less likely to be working full time, 3.6 percentage points less likely to be working part time, and thus 10.6 percentage points more likely to be retired than are individuals in jobs that are less physically demanding. ${ }^{9}$ Moreover, difficulty of work bears a stronger and stronger relation to retirement as an individual moves from his late 50 's through his $60^{\prime} \mathrm{s}$.

From the fourth panel, poor health is associated with a higher probability of retirement, increasing this probability by 28 percentage points on average. Poor health is also associated with a 2 percentage point increase in the probability of partial retirement and correspondingly is associated with a reduction in the probability of full-time work by 31 percentage points. Prior to age 65 , poor health depresses ful1-time work by a roughly constant amount, and thereafter the effect diminishes in absolute terms but not so much relative to the level of full-time participation. With regard to partial retirement, 
those in poor health are more likely than those in good health to be partially retired during the late $50^{\prime}$ s and early 60's, but after that age the situation is reversed. It should be noted that in these descriptive statistics we do not distinguish between those in poor health who are and are not receiving disability payments, but those receiving SSDI payments are distinguished in our later empirical analysis.

Interactions are also quite important, as can be inferred from the last panel of the table. Blacks in good health who hold physically demanding jobs are 5 percentage points more likely than comparably situated whites to be working full-time, and are 8 percentage points more likely if they hold less physically demanding jobs. On the other hand, blacks in poor health are less likely than whites to be working full-time, by 3.5 and 4.8 percentage points respectively. In other words, poor health is associated with a larger reduction in the probability of working full-time for blacks than for whites, and a corresponding increase in the probabilities of full and partial retirement, even controlling for differences in job mix between blacks and whites. 10

Differences in retirement outcomes between blacks and whites not only reflect differences between those in the same occupation and with similar health status, but they also arise because blacks have a much higher probability than do whites of holding jobs that are more physically demanding to perform and also have a much higher probability of having a long term health problem that limits ability to work. Analogously, differences in retirement behavior between those in more difficult and less difficult jobs and between those in poor and good health reflect differences in the composition of each broad group. These differences can be seen in the data in Tables 2 and 3 . Table 2 indicates the relevant weights in the sample for each of the eight groups defined by race, difficulty of work and health status, and relevant conditional percentages for 
these weights are reported in Table 3. From these data it is clear that disaggregating the estimation of relevant behavioral functions as we do here is an exercise that may help us to understand better what determines retirement behavior of older Americans in the aggregate, as well as the separate retirement behavior of those falling into each of the eight groups mentioned above.

\section{The Mode 1}

In order to analyze further the reasons for differences in retirement probabilities observed in Tables 1 and 2 , and to facilitate an analysis of the effects of the 1983 Social Security reform on those in difficult jobs and in poor health, a separate structural model of retirement behavior is specified and estimated for each race-occupation group, with health status being allowed to affect both the utility function and the opportunity set. Each individual is presumed to be trying to maximize a lifetime utility function of the form

$$
U=\int_{0}^{T} u[C(t), L(t), t] d t
$$

where $C(t)$ is consumption at time $t, L(t)$ is leisure at time $t$, and $T$ is the relevant time horizon over which the maximization is done. This utility function is maximized with respect to consumption, leisure, and work effort subject to the lifetime budget constraint

$$
\int_{0}^{T} e^{-r t}[Y(t)-C(t)] d t+A_{0}=0
$$

where $A_{0}$ is initial assets, $Y(t)$ is compensation at time $t$ (including any increments to the present value of Social Security and pension benefits), and $r$ is the real interest rate. $Y(t)$ and $L(t)$ take on values of $Y_{F}(t)$ and $L_{0}$, respectively, if the individual chooses full-time work; otherwise, they take on values of $Y_{p}\left[H_{p}(t)\right]$ and $1-H_{p}(t)$, respectively, where $H_{p}(t)$ is the amount of labor supplied to the partial retirement job and is restricted to be less 
than $1-L_{0} . \quad Y_{p}[\cdot]$ is the function relating partial retirement work effort to compensation and reflects the effects of Sociar Security and pension rules on compensation, given the actual wage rate.

The utility function used in the empirical work is of the following CES specification:

$$
u[C(t), L(t), t]=\operatorname{sign}(k)\left\{[C(t)]^{k}+\left[\exp \left(x_{t}^{\prime} b+e\right)\right][L(t)]^{k}\right\}
$$

where $\underline{x}_{t}$ is a vector of explanatory variables which affect the relative weight of leisure in the utility function at time $t$ and $\underline{b}$ is the associated vector of parameters which is presumed to be constant across both time and individuals. $k$ (with $k<=1$ ) is a time-invariant stochastic term defining the curvature of the indifference curves for each individual. It is presumed to come from the exponential distribution

$$
f(k)=\exp [-g(1-k)], \quad k<=.1
$$

where $g$ is a positive parameter defining the distribution. $e$ is a timeinvariant stochastic term reflecting the relative weight that the individual places on leisure, and it is assumed to be distributed normally with the parameters $N\left(p k, s_{e}^{2}\right)$, with the parameter $p$ providing a means by which $k$ and e may be correlated. In this specification, which follows that used by Gordon and Blinder, the within-period elasticity of substitution is calculated as $n=$ $1 /(1-k)$.

In this model, the time-varying elements of $x_{t}$ cause the individual to place an increasing weight on the leisure term in the utility function as he grows older. During the first part of the life cycle, the individual values leisure relatively little, and he will find it advantageous to work full-time and to spend the income on current or future consumption. At some point in time, however, the weight on leisure will grow sufficiently that it no longer 
pays the individual to work full-time. The age at which this happens depends in part on the value of stochastic term e; for otherwise identical individuals, a person with high value of e will quit full-time work at an earlier age than a person with low value of e. Whether the individual works part-time or retires completely at this point depends on the value of the second stochastic term, $k$. If an individual has a high value of $k$, which implies that his elasticity of substitution between leisure and consumption is high, then he is unlikely to find part-time work at a reduced wage a very attractive alternative relative to complete retirement. For an individual with a lower elasticity of substitution between consumption and Teisure, part-time work may be much less onerous than full-time work, and this individual will find the opportunity to work part-time more than offsets the fact that part-time wages are lower. Eventually though, the increasing weight on leisure in the utility function will cause even this individual to retire completely.

A number of caveats are in order regarding this model. First, the model takes as given whether an individual initially chose a more phyically demanding or a less demanding job and does not try to analyze the reasons for this choice. In terms of the model itself, each individual is given only one full-time compensation path $Y_{F}(t)$ and one part-time compensation function $Y_{P}[$.$] rather$ than a choice of two different sets of paths associated with more or less physically demanding work. This limitation implies that the model cannot be used to analyze the effects on retirement behavior that may result from individuals in more demanding jobs taking less demanding jobs instead, and vice versa.11 A second caveat is that the model assumes perfect foresight. The difficulty of estimating a structural model is increased very substantially when uncertainty is introduced even in a very simple way, so we leave further extension of the model in this direction to future work. It is partly for this 
reason and partly because of the problem of inferring the unhealthy individuals self assessment of the chances that he will eventually be determined to be eligible for benefits that the model does not incorporate the uncertainty associated with the eligibility determination process and with the waiting period of the DI program. The sum and substance of these limitations is that the parameters estimated for the utility functions will not be entirely clean and may be subject to such major changes in the very long term as those produced when mix of more demanding vs. less demanding jobs adjusts to changes in the opportunity sets. Nevertheless, the parameter estimates we obtain should provide a first approximation of individual responses of those in each group to changes brought about by Social Security reform, pension regulation, laws governing mandatory retirement, and other related changes.

\section{Empirical Estimates}

The parameters of the model are the elements of the vector $\underline{b}$ plus the parameters $g, s_{e}$ and $p$ which characterize the distribution of the stochastic terms. In order to estimate these parameters, it is necessary to impute values for $\underline{x}$ and for the compensation paths. Because of the complexity of the computations during the estimation procedure, the number of elements in $\underline{x}$ was kept to a minimum which includes a constant term, age, health status and vintage. The imputation of the compensation paths from the available data makes for a tedious discussion and is relegated to a data appendix. The essential idea of the imputations is to use whatever wage observations are available for the individual to infer the height of the compensation profile and to use estimated wage equations to provide the shape of the profile over time. At least one actual observation for full-time work was required for each individual in the sample so that at least the height of the overall full-time profile was based on something other than imputed information. 
The formulation of the likelihood function for the model has been discussed in detail elsewhere (Gus.tman and Steinmeier, 1983a), and that discussion wi11 not be repeated here. The essential idea of the estimation procedure is that the observed retirement sequence places limits on the possible values of $k$ and e for each individual, given the parameter values and the compensation path for that individual, and the procedure chooses parameter values so as to maximize the probability that the stochastic variables will lie within the prescribed region.

The estimation procedure was carried out separately for the four groups defined by the black/white and the more/less physically demanding job dichotomies. The resulting parameter estimates from the model are presented in Table 4, with standard errors indicated in parentheses below each figure. As can readily be seen, most of the parameters with the exception of the coefficient of vintage are highly significant at standard levels. Table 5 presents the results of chi-square tests for the equality of various pairs of coefficient sets. This is in essence a test of whether the parameter estimates for the four groups are significantly different from one another. The estimates for blacks and whites, whether in more or less demanding jobs, are significantly different from one another at much better than a $1 \%$ significance level. The estimates for more vs. less demanding jobs are significantly different for whites at the $1 \%$ level but for blacks only marginally significant at the $5 \%$ level. A glance at Table 4 suggests that the sharpest differences among the groups is between whites in more demanding jobs and the other three groups, and the chi-square statistics are indeed higher for comparisons involving this group, even considering that this group has relatively more observations.

In interpreting what differences between these coefficient sets mean, it is important to keep in mind that the differences can arise from two distinct sources with different implications. First, since the groups are doing 
different kinds of jobs, the disutility of each additional hour of work will in general be different for the various groups, and this disutility may be affected in different ways among the groups by such factors as age and health. This is obviously true for the groups with more vs. less physically demanding jobs. But it may also be true for blacks vs. whites, since for example within the physically demanding job group blacks may have the most demanding jobs (see footnote 10). Secondly, the underlying tastes for work may vary among the groups, and this can also affect the parameter values. For the black/white dichotomy these differences may be regarded simply as distinctions among groups, while for the more/less demanding job dichotomy the differences in underlying tastes may have their origins in a self-selection process during the time people choose their occupations. The expectation would be that people with more of a distaste for physically demanding work would sort themselves into occupations in which they will not encounter it, and oppositely for individuals with less of a distaste for that kind of work. The parameter values for the various groups reflect both of these factors, namely the actual difficulty of the group's work and the preferences of the group for demanding or undemanding jobs, and it will not be possible to separate these two factors without a considerably more complicated model which explicitly looks at the sorting process by which individuals choose the type of work they do.

In looking at the specific parameter estimates, four of the parameters are of particular interest. The central parameter of the model is $b_{1}$, the coefficient for age, since the greater the value of this parameter, the faster the disutility of work will be growing with age and the less responsive will the retirement decision be to any kind of economic incentives. Among the four groups, the value of $b_{1}$ varies considerably but not excessively, and there-is no obvious pattern. A second important parameter is $s_{e}$, with measures the 
dispersion of tastes for work and leisure. Of particular significance is the value of this parameter relative to $b_{1}$, since this ratio may be thought of as the number of years that it takes for an individual's disutility of work to increase by an amount representing one standard deviation of the dispersion of tastes. In this sense, the major pattern in the figures would appear to be that blacks have more dispersed tastes for work than do whites in the corresponding class of jobs.

The third parameter of interest is $b_{2}$, the coefficient of the poor health indicator. This parameter can be interpreted relative to $b_{1}$ in much the same way as was $s_{e}$, and again it would appear that the estimated impact of poor health is greater for blacks than for whites in the same class of jobs. (Notice that the health indicator is not interacted with age, so $i 11$ health increases once and for all the disutility of work, but does not further affect the shape of the relation between age and disutility of work within any of the four groups considered.) The final parameter of importance is $g$, which governs the distribution of the elasticity of substitution between consumption and leisure in the utility function. The higher the value of this parameter, the more concentrated will be preferences in inelastic values of the substitution elasticity. As is readily evident from the first line of the table, all the groups have relatively similar values of this parameter except for whites in more difficult jobs, who appear to have more elastic preferences between consumption and leisure. This has two expected consequences for retirement behavior. First, for any given set of compensation paths, this group would be expected to enter partial retirement less frequently. And secondly, the higher substitution elasticities imply that a uniform upward shift in the lifetime compensation streams will have less of a negative effect on retirement for this group than for other groups. 


\section{Using The Model To Analyze Differences In Retirement Rates}

In order to gain insight into what underlies the observed differential in the retirement rates between two groups, there is a natural exercise which is suggested by the model. It is possible to ask what part of the difference in labor market outcomes reflects the effects of differences in opportunity sets and what part reflects differences in utility functions. More explicitly, let u(.) represent the preference function appropriate for a particular group. This preference function reflects both the effects of the utility function parameters in $\underline{b}$ and the parameters defining the distributions of the stochastic error terms $k$ and $e$ for that group. Similarly, let o(.) represent the opportunity set for that group, including both the compensation streams $Y_{F}(t)$ and $Y_{P}[\cdot]$ for the various individuals in the group and the Tevel of health of the individuals in the group. The retirement outcome for the particular group can then be written as $R[u(),. o()$.$] . Using this notation, the$ difference between, for example, the groups with more or less physically demanding jobs may be written as $R[u(m), 0(m)]-R[u(1), 0(1)]$, or $R(m, m)-R(1,1)$ for short.

In turn, this differential may be decomposed into the sum of two component differentials, one resulting from differences in $0($.$) and the other from$ differences in $u($.$) between the groups. Using the notation developed above,$ they may be written, definitionally, as either $[R(m, m)-R(m, 1)]+[R(m, 1)-$ $R(1,1)]$ or as $[R(1, m)-R(1,1)]+[R(m, m)-R(1, m)]$. The first bracketed term in both expressions represents the effect of the differences in $0($.$) between$ the groups. In the first expression this difference is calculated using the $u($.$) for those in more demanding jobs, while in the second expression the$ calculation uses the $u($.$) of those in less demanding jobs. The second$ bracketed term in each expression represents the effect of differences in $u($. between the groups, this time calculated using the $O($.$) of those with less$ 
demanding jobs in the first expression and of those with more demanding jobs in the second expression.

\section{Retirement Differences According To Occupation}

The predicted values from the model for the differences in the probabilities of observing each of the retirement outcomes between those in more physically demanding vs less physically demanding jobs are reported in the first line of Table 6 . These predictions compare well with the corresponding descriptive statistics in Table 1 . Those differences were $-0.070,-0.036$, and 0.106 for the probabilities of nonretirement, partial retirement and full retirement respectively.

The second and third lines of the table describe that part of the the overall difference that can be accounted for by differences in the compensation paths and in the health status between the two groups. The second line makes this calculation using the utility function parameters for those in more demanding jobs, while the third line uses the parameters for those in less demanding jobs. The two calculations agree fairly well that a significant fraction, but substantially less than half, of the overall difference can be attributed to this source. The final two lines of the table show agreement that the major part of the overal1 difference in retirement outcomes arises from differences in the utility function parameters, regardless of whether the calculation is done using the opportunity sets for those in more demanding or less demanding jobs.

In interpreting the results of this table, it should be kept in mind that the second and third lines do not answer the hypothetical question: what would be the result of taking individuals in more physically demanding jobs and giving them less demanding jobs? They do answer the somewhat more restricted question: what would be the result of taking these individuals and giving them the 
compensation streams and the health levels of those in less physically demanding jobs, but keeping the nature of work the same as it currently is? Similarly, the last two lines answer the question: what is the combined effect of differences in preferences and of differences in the difficulty of work between the two groups? That these two effects are combined arises because both are reflected in the same utility function parameters, and particularly in those parameters which describe the disutility of work effort. With this interpretation, the result that most of the difference in retirement behavior between these two groups comes from the combined effect of preferences and job difficulty, as opposed to compensation streams or health levels, appears quite plausible.

Black-White Differences

The first line of Table 7 reports on the simulated black/white differences in retirement behavior. These differences compare with the observed values of $-0.020,0.002$, and 0.017 reported in Table 1 . There is reasonably close agreement between the simulated and observed differences for ful1-time work, but there is a moderate discrepency for partial retirement, and to a lesser extent, for full retirement. For either the simulated or the actual figures, however, the central feature is that they are not very large, particularly in contrast to corresponding figures in the 0.06 to 0.10 range for the more/less physically demanding job comparison.

The remainder of this table suggests that the mild black/white overall differential is composed of two offsetting effects, at least as far as ful1-time work and ful1 retirement are concerned. From the second and third 1 ines of the table, the effects of the utility function parameters are to reduce full-time work of blacks relative to whites by around 6 percentage points and to increase both full and partial retirement. Such an effect could arise either from 
stronger preferences of blacks for leisure or from the fact that within the broad job classifications, blacks have more physically demanding work. As noted before, the model cannot distinguish between these two causes. Offsetting this effect to some degree, the fourth and fifth 1 ines of the table suggest that the black compensation paths and health status encourage more full-time work and less full retirement relative to those for whites. This last result is mildly surprising and raises the natural question: what is it in the black opportunity sets that would encourage them to work more than would the white opportunity sets?

Attempts to decompose the impact of the opportunity sets suggests that this impact is itself the result of offsetting components. First, black health levels are in general poorer than those of whites. Simulations investigating the effect of health status operating both through wage levels and through the vector $\underline{x}$ of explanatory variables in the model suggest that the differential health status (including a differential SSDI eligibility rate) should reduce ful1-time work of blacks by 4.2 percentage points relative to that of whites. The major offsetting effect to this appears to come from the fact that general black compensation levels are substantially lower than for whites. Simulations indicate that a 50\% compensation advantage for whites would account for a 3.6 percentage point increase in full-time work effort by blacks relative to whites, if measured using black utility function parameters, and a 1.7 percentage point increase if measured using white utility function parameters. 12 Further offsetting effects come from Social Security and pensions; simulations suggest that each of these increase black ful1-time effort by about 0.5 percentage point relative to that of whites. From the simple sum of these components, it would appear that the black opportunity sets should increase full-time work, relative to white opportunity sets, by an amount ranging from -1.5 to 0.4 percentage 
points. The four effects discussed in this paragraph thus appear to be roughly offsetting, leaving the net positive effect of black opportunity sets on ful1time work effort to be accounted for either by interactions among the four separate effects or by other less obvious types of differences between black and white opportunity sets.

\section{Effects of The 1983 Social Security Reforms}

In this section, we simulate the effects of the changes in the Social Security law in the long term by contrasting the steady state retirement behavior which would be expected under the 1977 rules with the steady state behavior which would be expected under all of the provisions ultimately called for by the 1983 amendments. In the simulations, individuals are assumed to count their spouse's benefits as if they were their own. Details of the simulation procedure are reported in Gustman and Steinmeier (1983b). Two important assumptions made in the simulation should be noted, however. First, because the simulation is meant to address long-run steady state retirement rates, it is assumed that each worker is employed in a covered job for 35 years. Secondly, for the same reason it is assumed that there is no ceiling on covered earnings. Thus the incentives for continued work which were observed for the period of the $60^{\prime}$ and $70^{\prime} \mathrm{s}$, which are based on replacing years of zero or low maximum ( $\$ 3000)$ covered earnings in an average monthly earnings calculation with a relatively small number of years in the average, do not play the same strong role in these simulations as they did in the earlier simulations, which used the actual Social Security rules in place during the sample period.

The 1983 legislation changed a number of elements of the Social Security system. The major provisions of the legislation considered include: (a) the eventual increase in the age of normal retirement to 67 , with the associated increase in the penalty for retirement at age 62 to 30 percent, (b) the eventual 
increase in the delayed retirement credit to 8 percent per year for benefits that are lost after the normal retirement age, (c) the reduction in the rate at which benefits are lowered for earnings over the test amount to one dollar of benefits foregone for every three dollars in earnings over the test amount (this provision applies only to individuals over the normal retirement age), and (d) the delay by six months in the inflation adjustment to benefit levels. 13

The provisions of the 1983 law listed above would appear to have greatest effect on those over 65. Our earlier work suggested that the major impact of the new Social Security law operated through the increase in the delayed retirement credit, which made the benefit structure approximately actuarially fair, with noticeable effects from increasing the age of normal retirement. As would be expected, our current simulations reflect this result for each of the separate groups analyzed here. Work effort rises by two to three times as much for 65 to 69 year olds as a result of this legislation as it does for the sample weighted average of 58 to 72 year $01 \mathrm{ds} .14$

Table 8 reports the absolute change in retirement rates and the percentage change which results for 65 to 69 year olds as a result of the 1983 legislation. The 1983 reforms are seen to increase full-time work activities and reduce the rates of both partial and full retirement for a 11 groups between 65 and 69 . These increases are substantial, corresponding to large proportionate increases in full-time work effort by these older individuals. From these results, it would appear that Congressional concern about inability of certain groups to respond to increased work incentives is not always borne out. The reason is that retirement levels for a particular group do not provide a reliable clue as to responsiveness of retirement rates of the group to changes in retirement incentives. For example, the increase in the percentage working full-time due to the 1983 rules is at least as great if not greater among white males in more physically demanding jobs than among white males in less physically demanding 
jobs despite the fact that percentage of those working in more demanding jobs is less than the comparable percentage in less demanding jobs. Even among those in poor health, who have a much reduced probability of working full-time, the percentage increase in full-time work is comparable those in good health. In terms of the absolute response, though, it appears those in poor health have a third to over a half of the response to work incentives as those in good health. None of this means that after the 1983 reforms we can expect older workers to return to the market in droves. The incentives create additional work effort among exactly the age group that some feel should, in light of improving longevity, be permitted, and indeed encouraged, to continue to work. It should not be forgotten, however, that these work increases brought about by the act are added to a low level of full-time work activity. The simulations indicate that under the 1983 reforms the rates of full-time work for 65 to 69 year olds in the same order for the categories as in Table 8 would be $.238, .302, .089, .116$, $.292, .388, .135$ and .151 respectively.

In addition to their effect on labor force behavior, another important question about the 1983 reforms is their effect on the incomes of older Americans. The data in Table 9 address this issue. The first row of this table indicates the net change in the present discounted value of Social Security benefits for the group which can be expected under the 1983 rules, expressed as a percentage of the expected benefits under the 1977 rules. For example, whites in good health with more demanding jobs can be expected to lose about 12.4 percent of the present value of their benefits under the new rules. The second row of this panel indicates the amount by which increased work creates additional labor earnings for the group, again expressed as a percentage of the present value of the Social Security benefits. For whites in good health in more demanding jobs, increased labor earnings should increase income by about 6.5 
percent of the present value of Social Security benefits, and hence the net effect of the 1983 rules for this group will be to reduce total lifetime income by about 5.9 percent of the present value of Social Security benefits. A roughly similar story emerges for those in good health in less demanding jobs. In general, the net loss of income--a lost that clearly understates the welfare loss to older individuals from reduced benefits because it ignores the value of leisure--is about 6 percent for those in good health and about 10-12 percent for those in poor health.

Within each group, those who retire after 65 will have a much milder loss of income than those who retire before 65, for two reasons. First, the labor supply response of individuals who are sti1l working at 65 will be considerably stronger, so most of the increase in labor earnings will be concentrated among this group. Secondly, the fact that the new rules will be more actuarially fair to this group will mitigate the general decline in the benefit structure under the new rules. The fact that the income loss of those in poor health is higher than for those in good health largely reflects the fact that a smaller percentage of those in poor health are still working at 65. In short, for those who would have retired before age 65 under the 1977 rules, it is just as some in Congress feared. Benefits are reduced proportionately more for this group, individuals in poor health or in a more demanding job are more likely to have retired by this age, and the incentives produce no counteracting increase in work effort. 15 However, for those who would have retired at 65 or later under the 1977 rules, the incentive effects in the new law should work.

A clear implication of this work is that ignoring the behavioral response to incentives contained in the 1983 Social Security reforms wi11 cause important offsetting effects of these responses, counteracting the initial decline in benefits, to be overlooked. Our model predicts that. increased earnings from work responses eventually will amount from a sixth of the benefit reduction to 
more than half of the lifetime reduction in Social Security benefits. Thus as in other areas of policy analysis (e.g. see Gustman, 1984), it is important in the retirement area to include behavioral responses when analyzing the effects of policy changes.

\section{Conclusions}

Disaggregation has provided useful information about the retirement behavior of blacks and whites, those in more or less physically demanding jobs, and those in good and poor health. We have been able to decompose the reasons for these intergroup differences into those reflecting differences in budget sets and those reflecting differences in estimated preference functions. Thus we have been able to extend a standard type of study--the analysis of intergroup differences in a labor market outcomes--by utilizing recent developments in the econometric estimation of labor supply through the use of maximum likelihood techniques. Moreover, this study has simulated the effects of recent Social Security reforms on groups that congress felt would be more adversely affected by the reforms, groups that were of sufficient concern to congress that they mandated a study of this type. A number of these concerns are borne out by the estimates, essentially because those in demanding jobs and in poor health are more likely to retire early, and none of the incentives in the new law have major effects for those under 65. Interestingly, however, the analysis indicates that average retirement rates for a group may prove to be a misleading indicator of the group's marginal responses to policy change, and specifically that the labor supply responses of those in demanding jobs to incentives to postpone retirement are as large as the responses of those in less demanding jobs. The simulation predicts that even those in poor health will exhibit a response to incentives, one that is half as large as the response of those in good health in absolute terms, and proportionately just as great. These labor 
supply responses are large enough to amount to from one sixth to one half of the social security benefit reductions contained in the 1983 amendments.

In considering these conclusions, several caveats which were mentioned throughout the paper should be kept in mind. First, the measurement of health status is a dichotomous variable based on the individual's self-response to a question asking for health problems which limited work or housework, and such a variable may be subject to considerable measurement error. Secondly, the initial choice between a more or less physically demanding job is taken as given, so that any change whose major impact operates through occupational choice cannot be analyzed very well. Thirdly, the model employed in the investigation assumes perfect foresight and is hence inappropriate for analyzing the short-run effects of any changes. Finally, SSDI participation is not explicitly modelled, both because the RHS contains little information which would enable reasonable imputations of an individual's self-assessment of his probability of being accepted into the program if he applied and because the treatment of such participation would require explicitly incorporating the disability determination process at the agency level. Despite these caveats, the parameter estimates we obtain should provide a first approximation of individual responses of those in each group analyzed to changes brought about by Social Security legislation, pension regulation, laws governing mandatory retirement, and other related changes. 


\section{Footnotes}

1. Structural analyses have been conducted in which both the utility function and the budget constraint are suitably specified for a life cycle model, replacing the single period specification utilized in earlier studies. Gordon and Blinder (1980) pioneered in the estimation of a structural, life cycle retirement model. For recent efforts see fields and Mitchel1 (1984), Burtless and Moffitt (1984) and Gustman and Steinmeier (1983a). Available structural analyses of retirement have not, however, analyzed seriously the differences in retirement behavior between black and white males and the reasons for these differences. There has been some effort to understand differences by race in labor force participation by middle aged and younger males. These latter analyses have has been concerned primarily with the impact of disability insurance on labor force participation. See, for example Leonard (1979), Parsons (1980b), Haveman and Wolfe $(1982,1984 a, 1984 b)$, and Halpern and Hausman (1984).

2. The 1983 Social Security amendments require of the Secretary of Health and Human Services that:
"The Secretary shall conduct a comprehensive study and analysis of the implications of the changes made by this section in retirement age in the case of those individuals (affected by such changes) who, because they are engaged in physically demanding employment or because they are unable to extend their working careers for health reasons may not benefit from improvements in longevity."

3. The 1983 amendments to the Social Security Act contain a number of provisions which reduce benefits for future recipients below what was called for under previous legislation. Reducing benefits disturbed many Congressmen because of the ir special concern for those who retire early because $i 11$ health and/or the requirements of physically demanding jobs make adequate performance difficult or impossible once one advances beyond prime age. Indeed, it is concern for such individuals that led to the institution of early retirement benefits under Social Security in 1961. (See Staff Paper, Special Committee on Aging, U.S. Senate, "Social Security Disability, Past, Present and Future," March 1982, p. 32.) Nevertheless, the changes brought about by the amendments, and especially the gradual increase in the age at which normal benefits are paid from 65 to 67 , reduced benefits substantially for those retiring early. Some in Congress held out the hope, or at least the rationalization that despite the negative simple correlation in time series data between longevity and the typical age of retirement, that increasing longevity, together with the stronger work incentives incorporated in the 83 law, would eventually lead to an increase in work by older individuals, with resulting increases in their earnings offsetting benefit reductions from the new amendments.

4. The Retirement History Study covers a sample of 11,153 individuals who were 58 to 63 year olds in 1969, and were surveyed biennially through 1979 . For more information on this survey, see U.S. Department of Health, Education and Welfare, Social Security Administration, Office of Research and Statistics, Almost 65: Baseline Data From The Retirement History Study, (Washington, D.C., GP0, 1976). To keep the descriptive statistics on the same basis as the later simulations, the average figures presented 
pertain to 58 to 72 year olds. Including the 73 year olds in the social security simulations would have involved an extensive amount of additional programming.

5. We have examined elsewhere the effects of using alternative measures of retirement status on the estimates obtained in reduced form retirement equations, for example the effects of classifying individuals as partially retired if they have experienced a fifty percent drop in either wages or in hours of work. The effect appears to be minor. (Gustman and Steinmeier, 1984)

6. In measuring the impact of health status on retirement, two issues may be noted. One is that measurement error in the health variable arises because individuals have incentives to misreport health status, both because some program benefits are conditioned on health status and because there may be some stigma attached to early retirement that is not brought about by a health problem, leading some to rationalize their behavior by exaggerating health problems. A second measurement issue arises because health is a choice variable that can be affected by deliberate investment activities (Eg., see Grossman ,1972, Menefee, 1980, and Bartel and Taubman 1979). A direct implication is that instead of health status causing retirement, both may be jointly determined. Indeed, as Lee (1982) has demonstrated, the wage and health may be treated as jointly determined endogenous variables. Although a complete analys is of the relation between health and retirement should probably treat investment in health, health status and the wages paid for full-time and part-time work as jointly determined outcomes, such an approach cannot be supported by the data and its requirements are beyond our current capabilities for econometric estimation.

7. The questions which arise about the usefulness of timing of subsequent death as an indicator of current health status are closely related to the questions which arise in the debate about the nature of the relationship between advances in medicine, which increase longevity, and the health status of the surviving population. To be sure, advances in medicine make many older individuals more active than they otherwise would have been. However, some whose lives have been prolonged may be in relatively poor health. For further discussion see Haveman and Wolfe(1984a), Andrisanni (1977), Butler (1983), Feldman (1983), Kingson (1981, 1982, 1983) and Meyers $(1982,1983)$.

8. Note that the two groups of occupations classified as more or less physically demanding differ in other ways than just in terms of difficulty of work. For example, the set of jobs labeled here as more physically demanding include blue collar jobs for which pension coverage is more likely. The effects of these and other differences between jobs on retirement behavior will be explored below. (See Quinn, 1978, for a reduced form analysis of the relation between nonpecuniary aspects of jobs and retirement rates. )

9. The relative differences are preserved when occupation on last job, or on longest job, is used instead of job held in 1969.

10. Although in this paper we treat blue collar jobs as "physically demanding," it is important to note that in the remaining set of jobs which they hold blacks also are likely to face tasks which are more physically 
demanding. Specifically, $9 \%$ of the wage observations for whites pertain to those employed in service occupations, $22 \%$ of those for blacks do.

Moreover, despite the fact that service occupations do not involve the kind of systematic pacing and repetitive activities of production work, some service jobs may be quite physically demanding. Over one third of whites are in professional, managerial, clerical and sales occupations, while not quite $20 \%$ of blacks are. To the extent that within each broad occupational category blacks hold more difficult jobs than do whites, we will estimate a higher disutility of work for blacks than for whites. This will convey no information on relative preferences of each group for leisure, nonpecuniary aspects of jobs constant.

11. The use of only two broad occupational categories may mitigate some of these problems. The problems would be more severe if a number of narrow occupational categories were used.

12. The 3.6 figure was obtained from a simulation which increased the black compensation paths, both full-time and part-time, by $50 \%$. The 1.7 figure was obtained from an analogous simulation in which the compensation paths for whites were lowered by $33.3 \%$. The fact that the effect appears to be substantially lower using the white utility function parameters is probably due to the fact that the estimated distribution for $k$ for whites in more physically demanding jobs favors a more elastic substitution between consumption and leisure, which would in turn reduce the size of a negative income effect on work effort.

13. Another provision of the amendments, the taxation of half of the benefits if total income exceeds a given income level, could not be simulated very well within the context of the present model. The given income level is high enough so that very few individuals in the sample would be affected on the basis of labor earnings alone, and the model is probably not very robust in terms of simulating non-labor income. For further discussion on this last point, see Gustman and Steinmeier (1985). Also, because the simulations use the compensation functions of the RHS cohorts, they may do less well in predicting labor market outcomes in future years for black males than for white males if the compensation opportunities have changed more for blacks than for whites.

14. The average increase for 58 to 64 year olds in the rate of ful1-time work associated with the 1983 reforms, whatever their occupation and health status, is never more than one-half of one percentage point. Those in poor health in this age range were seen in Table 1 to be about 37 percentage points less likely to be working full-time than were healthy individuals. Those in this age range who held demanding jobs were 4 to 9 percentage points less likely to be working full-time than were individuals in less physically demanding jobs.

15. Although those in poor health who retire before age 65 generally lose the most under the 1983 rules, those whose health is poor enough to qualify them for SSDI benefits should not lose much if anything. Those who qualify for SSOI benefits are eligible for the full primary insurance amount immediately, and the primary insurance amount calculation is not affected by the new rules (the general reduction in benefits is enforced instead through a later normal retirement age and an increased penalty for early retirement). Hence the benefits of those who receive SSDI are not adversely 
affected under the new rules. Indeed, the incentives to apply for SSDI are clearly enhanced by the 1983 reforms, although greater stringency in enforcement observed in recent years will counteract these incentives. 
Table 1

Retirement Probabilities By Race, Difficulty of Work and Health 58 To 72 Year 01d Males

$\begin{array}{ccc}\text { Not } & \text { Partially } & \text { Fully } \\ \text { Retired } & \text { Retired } & \text { Retired }\end{array}$

By Age

$\begin{array}{llll}58 \text { to } 72 & 0.404 & 0.149 & 0.447 \\ 58 \text { to } 61 & 0.811 & 0.064 & 0.126 \\ 62 \text { to } 64 & 0.548 & 0.138 & 0.314 \\ 65 \text { to } 69 & 0.173 & 0.197 & 0.630 \\ 70 \text { to } 72 & 0.082 & 0.172 & 0.747\end{array}$

Differences Between Groups By Age: Blacks - Whites

$\begin{array}{llrl}58 \text { to } 72 & -0.020 & 0.002 & 0.017 \\ 58 \text { to } 61 & -0.074 & 0.015 & 0.059 \\ 62 \text { to } 64 & -0.039 & 0.009 & 0.030 \\ 65 \text { to } 69 & -0.004 & -0.004 & 0.007 \\ 70 \text { to } 72 & -0.004 & -0.002 & 0.007\end{array}$

Differences Between Groups By Age: MPD Jobs - LPD Jobs

$\begin{array}{llll}58 \text { to } 72 & -0.070 & -0.036 & 0.106 \\ 58 \text { to } 61 & -0.043 & -0.013 & 0.056 \\ 62 \text { to } 64 & -0.094 & -0.016 & 0.111 \\ 65 \text { to } 69 & -0.096 & -0.050 & 0.146 \\ 70 \text { to } 72 & -0.038 & -0.068 & 0.106\end{array}$

Differences Between Groups By Age: Poor Health - Good Health

58 to 72

58 to 61

62 to 64

65 to 69

70 to 72
$-0.306$

$-0.378$

$-0.366$

$-0.159$

$-0.082$
0.022

0.072

$-0.058$

$-0.030$

$-0.049$
0.284

0.306

0.308

0.189

0.130

By Group

White, MPD Job, Good Health

White, LPD Job, Good Health

Black, MPD Job, Good Health

Black, LPD Job, Good Health

White, MPD Job, Poor Health

White, LPD Job, Poor Health

Black, MPD Job, Poor Health

Black, LPD Job, Poor Health
0.495

0.528

0.548

0.606

0.178

0.259

0.143

0.211
0.124

0.155

0.144

0.137

0.136

0.192

0.150

0.191
0.381

0.316

0.308

0.257

0.685

0.549

0.707

0.789 


\section{Table 2}

Population Weights By Race, Difficulty of Work and Health

Good Health Long Term Health
Problem
White, MPD Job
0.280
0.180
White, LPD Job
0.285
0.162
Black, MPD Job
0.032
0.029
Black, LPD Job
0.018
0.013

Table 3

Conditional Percentages Calculated From Population Weights

$\begin{array}{lrrr}\text { Base Population } & \% \text { Black } & \% \text { in MPD Jobs } \begin{array}{r}\% \text { with LT } \\ \text { Health Problem }\end{array} \\ \text { Blacks } & 100.0 & 66.5 & 45.0 \\ \text { Whites } & 0.0 & 50.8 & 37.7 \\ \text { In MPD Jobs } & 11.7 & 100.0 & 40.1 \\ \text { In LPD Jobs } & 6.4 & 0.0 & 36.6 \\ \text { In Good Health } & 8.2 & 50.8 & 100.0 \\ \text { In Poor Health } & 10.7 & 54.5 & 0.0\end{array}$


Table 4

Parameter Estimates of Utility Functions

\begin{tabular}{|c|c|c|c|c|c|}
\hline & & & & $87 a$ & \\
\hline & & MDJ & LDJ & MDJ & LDJ \\
\hline$g$ & $\begin{array}{l}\text { parameter for distri- } \\
\text { bution of } k\end{array}$ & $\begin{array}{c}0.781 \\
(0.022)\end{array}$ & $\begin{array}{c}0.543 \\
(0.074)\end{array}$ & $\begin{array}{l}0.478 \\
(0.036)\end{array}$ & $\begin{array}{c}0.546 \\
(0.066)\end{array}$ \\
\hline $\mathrm{s}_{\mathrm{e}}$ & $\begin{array}{l}\text { std. deviation } \\
\text { of } e\end{array}$ & $\begin{array}{l}0.775 \\
(0.009)\end{array}$ & $\begin{array}{l}1.400 \\
(0.005)\end{array}$ & $\left(\begin{array}{l}1.350 \\
0.029)\end{array}\right.$ & $\begin{array}{l}1.380 \\
(0.061)\end{array}$ \\
\hline$p$ & $\begin{array}{l}\text { correlation of } \\
k \text { and } e\end{array}$ & $\begin{array}{r}-11.270 \\
(0.070)\end{array}$ & $\begin{array}{l}-6.380 \\
(0.041)\end{array}$ & $\begin{array}{l}-6.160 \\
(0.137)\end{array}$ & $\begin{array}{l}-6.060 \\
(0.261)\end{array}$ \\
\hline$b_{0}$ & constant & $\begin{array}{l}-1.580 \\
(0.064)\end{array}$ & $\begin{array}{l}-6.650 \\
(0.152)\end{array}$ & $\begin{array}{l}-4.150 \\
(0.138)\end{array}$ & $\begin{array}{l}-1.940 \\
(0.225)\end{array}$ \\
\hline $\mathrm{b}_{1}$ & $\begin{array}{l}\text { coefficient of } \\
\text { age }\end{array}$ & $\begin{array}{l}0.160 \\
(0.009)\end{array}$ & $\begin{array}{c}0.230 \\
(0.007)\end{array}$ & $\begin{array}{l}0.210 \\
(0.009)\end{array}$ & $\begin{array}{l}0.160 \\
(0.018)\end{array}$ \\
\hline$b_{2}$ & $\begin{array}{l}\text { coefficient of } \\
\text { health indicator }\end{array}$ & $\begin{array}{l}0.630 \\
(0.060)\end{array}$ & $\begin{array}{l}1.070 \\
(0.217)\end{array}$ & $\begin{array}{l}1.090 \\
(0.144)\end{array}$ & $\begin{array}{l}1.330 \\
(0.239)\end{array}$ \\
\hline$b_{3}$ & $\begin{array}{l}\text { coefficient of } \\
\text { vintage measure }\end{array}$ & $\begin{array}{c}0.050 \\
(0.024)\end{array}$ & $\begin{array}{l}0.090 \\
(0.049)\end{array}$ & $\begin{array}{l}-0.070 \\
(0.057)\end{array}$ & $\begin{array}{l}-0.010 \\
(0.085)\end{array}$ \\
\hline & $\begin{array}{l}\text { median value of } k \\
\text { calculated from }\end{array}$ & 1.127 & 0.783 & 0.690 & 0.788 \\
\hline $\begin{array}{l}\text { num } \\
\text { obs }\end{array}$ & $\begin{array}{l}\text { er of } \\
\text { rvations }\end{array}$ & 510 & 366 & 281 & 129 \\
\hline $\log$ & Tikel ihood & -1251.58 & -986.24 & -753.83 & -358.84 \\
\hline
\end{tabular}




\section{Table 5}

Tests for Equality Between Pairs of Coefficient Sets

$\begin{array}{cc}\begin{array}{c}\text { Coefficient } \\ \text { Pairs }\end{array} & \begin{array}{c}\text { Test } \\ \text { Statistic } \\ \text { White MDJ and } \\ \text { White LDJ }\end{array} \\ \text { Black MDJ and } \\ \text { Black LDJ } & 42.70 \\ \text { White MDJ and } & 14.18 \\ \text { Black MDJ } & \\ \text { White LDJ and } \\ \text { Black LDJ }\end{array}$


Table 6

A Decomposition of Retirement Differences By occupation: Ages 58 to 72

$\begin{array}{lccc}\text { Not } & \begin{array}{c}\text { Partial1y } \\ \text { Retired }\end{array} & \begin{array}{c}\text { Ful1y } \\ \text { Retired }\end{array} \\ R(m, m)-R(1,1) & -0.060 & -0.023 & 0.083 \\ R(m, m)-R(m, 1) & -0.016 & -0.008 & 0.023 \\ R(1, m)-R(1,1) & -0.008 & -0.008 & 0.015 \\ R(m, 1)-R(1,1) & -0.044 & -0.017 & 0.060 \\ R(m, m)-R(1, m) & -0.052 & -0.015 & 0.068\end{array}$

Table 7

A Decomposition of Black-White Differences

In Full Time Work: Ages 58 to 72

$\begin{array}{lccc}\text { Not } & \begin{array}{c}\text { Partially } \\ \text { Retired }\end{array} & \begin{array}{c}\text { Fully } \\ \text { Retired }\end{array} & \begin{array}{c}\text { Retired } \\ R(b, b)-R(w, w)\end{array} \\ & -0.027 & 0.032 & -0.005 \\ R(b, w)-R(w, w) & -0.061 & 0.016 & 0.045 \\ R(b, b)-R(w, b) & -0.056 & 0.029 & 0.026 \\ R(b, b)-R(b, w) & 0.034 & 0.016 & -0.050 \\ R(w, b)-R(w, w) & 0.029 & 0.003 & -0.031\end{array}$


Table 8

Changes in Retirement Probabilities for 65 to 69 Year $01 d s$

Brought About By The

1983 Social Security Amendments

\begin{tabular}{|c|c|c|c|c|c|c|c|c|}
\hline & $\begin{array}{r}\text { GoOC } \\
\text { MPD }\end{array}$ & $\begin{array}{l}\text { Health } \\
\text { Jobs }\end{array}$ & $\begin{array}{l}\text { Poor } \\
\text { MPD }\end{array}$ & $\begin{array}{l}\text { Health } \\
\text { Jobs }\end{array}$ & $\begin{array}{r}\text { Good } \\
\text { LPD }\end{array}$ & $\begin{array}{l}\text { Health } \\
\text { Jobs }\end{array}$ & $\begin{array}{l}\text { Poor } \\
\text { LPD }\end{array}$ & $\begin{array}{l}\text { Health } \\
\text { Jobs }\end{array}$ \\
\hline & Wh & B 1 & Wh & B1 & Wh & B 1 & Wh & B1 \\
\hline $\begin{array}{c}\text { Ful1-time Work } \\
\% \text { change }\end{array}$ & $\begin{array}{l}.074 \\
45.1\end{array}$ & $\begin{array}{l}.059 \\
24.3\end{array}$ & $\begin{array}{l}.032 \\
56.1\end{array}$ & $\begin{array}{l}.020 \\
20.8\end{array}$ & $\begin{array}{l}.056 \\
23.7\end{array}$ & $\begin{array}{l}.067 \\
20.9\end{array}$ & $\begin{array}{l}.031 \\
29.8\end{array}$ & $\begin{array}{l}.022 \\
17.1\end{array}$ \\
\hline $\begin{array}{l}\text { Partial Retirement } \\
\% \text { change }\end{array}$ & $\begin{array}{l}-.028 \\
-19.9\end{array}$ & $\begin{array}{l}-.033 \\
-.170\end{array}$ & $\begin{array}{l}-.010 \\
-13.5\end{array}$ & $\begin{array}{l}-.006 \\
-5.3\end{array}$ & $\begin{array}{l}-.031 \\
-18.3\end{array}$ & $\begin{array}{l}-.049 \\
-18.6\end{array}$ & $\begin{array}{l}-.016 \\
-15.2\end{array}$ & $\begin{array}{l}-.010 \\
-6.2\end{array}$ \\
\hline $\begin{array}{l}\text { Fu } 11 \text { Retirement } \\
\% \text { change }\end{array}$ & $\begin{array}{l}-.046 \\
-6.6\end{array}$ & $\begin{array}{l}-.026 \\
-4.6\end{array}$ & $\begin{array}{l}-.022 \\
-2.5\end{array}$ & $\begin{array}{l}-.014 \\
-1.8\end{array}$ & $\begin{array}{l}-.026 \\
-4.4\end{array}$ & $\begin{array}{l}-.019 \\
-4.6\end{array}$ & $\begin{array}{l}-.015 \\
-1.9\end{array}$ & $\begin{array}{l}-.013 \\
-1.8\end{array}$ \\
\hline
\end{tabular}

Table 9

Changes in Lifetime Income Brought About

By 1983 Social Security Amendments

(as a fraction of initial lifetime Social Security Benefits)

$\begin{array}{lrrrrrrrr}\text { From: } & \text { White } & \text { Black } & \text { White } & \text { Black } & \text { White } & \text { Black } & \text { White } & \text { Black } \\ \text { Social Security } & -.124 & -.117 & -.138 & -.140 & -.113 & -.114 & -.134 & -.135 \\ \text { Labor Earnings } & .065 & .056 & .030 & .023 & .050 & .055 & .030 & .026 \\ & & & & & & & & \\ \text { Net Effect } & -.059 & -.061 & -.108 & -.117 & -.063 & -.059 & -.104 & -.109\end{array}$

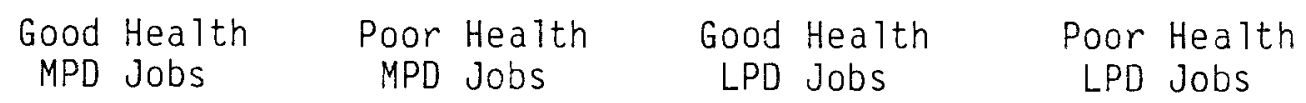

White Black White Black White Black White Black 


\section{References.}

Andrisani, Paul J. "Health Limitations and Labor Market Experience During The Preretirement Years" in Seymour L. Wolfbein, editor, Men in The Pretirement Years, Philadelphia, Temple University, $1977, \overline{p p} . \overline{9}-\overline{38}$.

Barte1, Ann and Taubman, Paul, "Health and Labor Market Success: The Role of Various Diseases," REStat, Feb. 1, 1979, LXI, No. 1, pp. 1-8.

Burtless, Gary and Moffitt, Robert A. "The Effects of Social Security On The Labor Supply of The Aged" in Henry Aaron and Gary Burtless, editors, Retirement And Economic Behavior, Brookings Institution, Washington, D.C., 1984.

Butler, Robert N., "Current Data Inconclusive About Aged's Health and Work," Aging and Work, vol. 6, no. 3, 1983.

Feldman, Jacob J., "Work Ability of the Aged Under Conditions of Improving Mortality," Aging and Work, vol. 6, no. 3, 1983.

Fields, Gary S. and Mitchell, 01 ivia S., Retirement, Pensions and Social Security, MIT Press, forthcoming.

Gordon, Roger H. and Blinder, Alan S., "Market Wages, Reservation Wages and.Retirement," Journal of Public Economics, vol. 14, 1980, pp. 277308 .

Grossman, Michae1, The Demand For Health: A Theoretical and Empirical Investigation, New York, National Bureau of Economic Research, 1972.

Gustman, Alan L., "Modeling Individual's Behavior: Evaluation of A Policy Maker's Tool," Journal of Policy Analysis and Management, Winter, 1984 , pp. 191-205.

Gustman, Alan L. and Steinmeier, Thomas L., "A Structural Retirement Mode1." National Bureau of Economic Research, Working Paper No. 1237 , October, 1983a.

Gustman, Alan L., and Steinmeier, Thomas L., "Social Security Reform and Labor Supply, National Bureau of Economic Research, Working Paper No. 1212 , October, 1983b.

Gustman, Alan L. and Steinmeier, Thomas L., "Partial Retirement and The Analysis of Retirement Behavior", Industrial and Labor Relations Review, vol. 37, Apri7, 1984, pp.403-415.

Gustman, Alan L. and Steinmeier, Thomas L., "The Effect of Partial Retirement on Wage Profiles of 0lder Workers," Industrial Relations, Spring, 1985.

Gustman, Alan L. and Steinmeier, Thomas L., "The 1983 Social Security Reforms and Labor Supply Adjustments of 01der Individuals In the Long Run," Journal of Labor Economics, Apri1, 1985, (forthcoming.) 
Halpern, Janice and Hausman, Jerry. "A Model of Applications For the Social Security Disability Insurance Program," mimeo, March, 1984.

Haveman, Robert and Wolfe, Barbara, "Disability Transfers and the Work Effort Response of 0lder Males: A Reconciliation," mimeo, 1982.

Haveman, Robert and Wolfe, Barbara, "The Decline In Male Labor Force Participation: Comment," Journal of Political Economy, June 1984(a), vol. 92 , No. 3 pp. 532-541.

Haveman, Robert and Wolfe, Barbara, "Disability Transfers and Early Retirement: A Causal Relationship," Journal of Public Economics, vol. $24,1984(b)$, pp. 47-66.

Kingson, Eric R., "The Health of Very Early Retirees," Aging and Work, vol. 4, no. 1, winter 1981, pp. 11-22.

Kingson, Eric R., "11-Critique Retirement Study Disputed," Aging and Work, vol. 5, no. 2, 1982 , pp. 93-110.

Kingson, Eric, "Still More About Early Retirement," Aging and Work, vol. 6, no. 2, 1983, pp. 111-116.

Lambrinos, James, "Health: A Source of Bias in labor Supply Models," Review of Economics and Statistics, May 1981, 206-212.

Lee, Lung-Fei, "Health and Wage: A Simultaneous Equation Model with Multiple Discrete Indicators," International Economic Review, vol. 23, No. 1,1982 , pp.199-221.

Leonard, Johnathan S., "The Social Security Disability Program and labor Force Participation," NBER Working Paper No. 392, August 1979.

Menefee, John, "The Demand for. Health and Retirement," in Robert L. Clark, editor, Retirement Policy in an Aging Society, Durham, Duke Press, 1980 , pp. 18-51.

Meyers, Robert J., "Health and Early Retirement Debate: I - Why Do People Retire From Work Early?" Aging and Work, vo1. 5, no. 2, 1982, pp. 8392.

Meyers, Robert J., "More About the Controversy on Early Retirement Study," Aging and Work, vol. 6, no. 2, 1983, 105-110.

Parsons, Donald 0., "The Decline In Male Labor Force Participation," Journal of Political Economy, February 1980a, vol. 88, pp. 117-134.

Parsons, Donald 0., "Disability Insurance and Male Labor Force

Participation: A Response to Haveman and Wolfe," Journal of Political Economy, vol. 92, no. 3, June 1984, pp. 542-549.

Parsons, Donald 0., "The Male Labor Force Participation Decision, Health, Reported Health and Economic Incentives," Economica, February 1982, vol. 49, pp. 81-91. 
Pärsons, Donald 0., "Racial Trends in Male Labor Force Participation Decisions," American Economic Review, December 1980, vol. 70, pp. 911920.

Quinn, Joseph F., "Microeconomic Determinants of Early Retirement: A Cross Sectional View of White Married Men," The Journal of Human Resources, Summer, 1977, vol. XII, No. 3, pp. 329-346.

Sickles, Robin C. and Taubman, Paul, "An Analys is of Health and Retirement Status of the Elderly," mimeo, July, 1984. 


\section{Appendix A}

The data base used in this study is the Retirement History Survey (RHS), a random longitudinat sample of approximately 11,000 households. Detailed questionnaires were administered to these households every two years from 1969 to 1979. The study excludes female-headed households and households in which the head was self-employed full-time in 1969, or if he was not employed at that time, was self-employed in his previous job. The study also excludes households if critical information is missing, although a major effort is made to impute missing information if at all possible. A11 remaining black households are included, but in order to produce comparable sample sizes and to avoid an overwhelming computational burden, only one in every five white households is included in the final sample used in the estimation and simulation of the model.

The sample is divided into four distinct groups according to the black/white dichotomy and the more/less physically demanding job dichotomy. The job category is determined by the individual's occupation in a fulltime job in 1969 , or in the last job if he was not employed full-time in 1969. For the estimation and simulations, it is necessary to calculate three distinct types of information for each individual in the sample: the compensation profiles for full-and part-time work, (ii) the individual's retirement sequence, and (iii) the values for the variables in the $\underline{x}$ vector. The compensation profiles, in turn, can be decomposed into components due to wages, pension benefits, and Social Security benefits. The major steps in the construction of the compensation profiles and the retirement sequences are described in the following section.

Wage Profiles. The first step in constructing the wage profiles is to estimate wage equations for the four groups. Then for each individual, the 
shape of the profile over time is inferred from the individual's work history as reported in the survey, in combination with the estimated coefficients of the experience, tenure, mandatory retirement horizon, and long-term health problem variables in the appropriate wage equations. The height of the resulting profile is adjusted to go through the center of whatever wage observations are available for the individual. The process is carried out separately for the full-time wage profile and the part-time wage profile, and individuals are dropped from the sample unless at least one actual full-time wage observation is available. This assures that at least the overall height of the full-time profile is based on actual information for the individual. For cases in which there are no observations for part-time wages, the height of the part-time profile is determined by the estimated equation.

For ful1-time wages, separate equations are estimated for the part of the profile over and under 55 years of age. This is done because the RHS includes individuals who were at least 58 in the initial year, and any projection of the profile before age 55 would necessarily rely on strong assumptions about the functional form of the experience and tenure variables. For that part of the profiles prior to age 55, equations are estimated from the Panel Study of Income Dynamics (PSID). The wage equations estimated from these two data sets are reported in Tables A1 and A2, respectively. A11 wages are deflated to 1967 levels using the index of hourly earnings, so that these estimates are net of the effects both of general price increases and productivity increases. 1

The form of the wage equations estimated from the PSID is reasonably standard. When similar equations are estimated from the RHS, the tenure and experience variables, both in quadratic and linear forms, imply a rate of wage decline for blacks in less demanding jobs that is implausibly large 
as compared with the actual wage changes observed for those who held the same job in successive surveys. Hence, a constraint is imposed in these equations to force the sum of the experience and tenure effects to match the average wage changes observed for individuals who held the same job in successive surveys.

Chow tests are performed on these equations to see whether separate equations are needed for the four groups. For the RHS, tests for the equality of coefficients between the equations for blacks vs. whites yield test statistics of 4.13 for more demanding jobs and 3.55 for less demanding jobs, both above the $1 \%$ critical value of 1.87 .2 A further test for differences between equations for more vs. less demanding jobs results in a test statistic of 11.25 for whites, which is substantially above the $1 \%$ critical level of 1.87 .3 For the PSID equations, the test for differences in the equations for more vs. Tess demanding jobs gives a statistic of 2.23 for whites, above the $1 \%$ critical level of 1.95 . Tests for black/white differences yields 2.90 for demanding jobs and 3.63 for less demanding jobs, both above the $1 \%$ critical level of 2.01 . The general conclusion from all of these tests is that the wage equations for these four groups do indeed show significant differences.

Table A3 reports the equations used for part-time wages. These equations are not separated according to the more/7ess demanding job dichotomy. For part-time work in jobs started before 55 , the test statistic for separate equations for more vs. Tess demanding jobs for whites indicates that such separation is not necessary. The statistic is 0.69 , well below the $5 \%$ critical level of 1.62 . For part-time work in jobs started after 55, the use of separate equations for more vs. less demanding jobs is avoided because it would require modelling the choice between the 
two, and it is doubtful that the data would support estimating the parameters associated with this additional choice. For all the part-time wage equations, the tenure and experience variables are excluded to simplify the control solution to the life-cycle problem. The test statistics for this exclusion are 1.22 for jobs started after age 55, which is below the $5 \%$ critical value of 2.57 , and 3.10 for jobs started before age 55 , which is above the $5 \%$ critical value of 3.41 but below the $1 \%$ critical value of 2.41 .

A rough imputation of the individual's complete job history begins with the starting and finishing dates for the individual's first, longest, last, and current jobs, as reported in the first survey year of the RHS. Additional jobs are assumed to fill whatever gaps are left in the job history after consideration of the first, longest, last, and current jobs. If there is no indication that the individual faced mandatory retirement, it is presumed that he could have continued indefinitely in his last fulltime job. If the individual did indicate that he faced mandatory retirement, it is presumed that after the mandatory retirement date, he could have begun a new full-time job in the same occupation, but at a wage rate which reflected a drop in tenure to zero, a return of the mandatory retirement horizon variable to zero, and an absence of pensions. With regard to part-time work, it is assumed that unless the individual was observed to work part-time in a job he held before age 55 , his opportunities to work part-time were limited to new jobs that began or would have begun after that age. This assumption is consistent both with findings pertainint to the relative frequency of part-time work in jobs begun before and after age 55 (Gustman and Steinmeier, 1984) and with information on the pervasiveness of lower limit constraints on hours of work on full-time jobs (Gustman and Steinmeier, 1983). 
The job history thus constructed provides the time path for the tenure, experience, and mandatory retirement variables over the individual's working life, and it indicates which part-time wage equation was or would have been appropriate for the individual. The effects of these variables on the individual's wages over time are then inferred from the coefficients of the wage equations, and any additional effects of longterm health problems on wages are handled in a similar fashion. Finally, after the wage paths are imputed, the effects of productivity increases over time are added back in by multiplying the wage by the ratio of the average hourly earnings index to the consumer price index.

Pensions. The pension component of compensation is calculated as the increase (or decline) in the total present value of expected pension payments which arises if the individual works in the job another year. For most individuals who are eligible for pensions, the RHS inquires about the age at which they could receive full benefits, the age at which they might be eligible for reduced benefits, and the amount of the benefits when they start to collect them. This provides sufficient information to make a. rough calculation of the pension component of compensation even though there is no information as to the specific form of the pension formulae in the RHS.

The pension calculations exploit the fact that most pensions are of the defined benefit type, and of those most use a formula in which annual payments are found by multiplying years of service times a base amount and adjusting the result downward if the individual has retired early. The base amount can be either a specific dollar sum or some percentage of the final average salary, but the important point for the present calculations is that in either case, the base amount for those still working is likely 
to be increasing roughly proportionately to increases in the wage levels. ${ }^{4}$ Where the figure is a stated dollar amount, as in the UAW pension plan, the amount rises as the union negotiates increased pension payments along with increased wages. Where it is a final average salary, it rises as the final average increases along with the general wage level.

Several auxiliary assumptions are used in the calculations. First, once an individual has retired, it is assumed that nominal pension payments increase at $37.9 \%$ as fast as prices (see Allen, Clark, and Sumner, Table 1) and that the individual projects inflation to be roughly the average inflation observed over the previous ten years. Secondly, it is assumed that once an individual reaches the normal retirement age under the plan, he does not accrue additional years of service for purposes of the pension if he continues to work. Finally, it is assumed that if an individual retires early, the amount by which the pension is reduced is given by the occupation-specific figures reported in Hatch et al (1981).

These assumptions, along with data about the individual's actual pension receipts and the ages for early and normal retirement associated with his pension plan, permit year-by-year calculations of the discounted value of benefits were the individual to retire in that year, and the difference between successive yearly calculations is then taken as the pension component of compensation. In cases where not all the data is available, imputations are done as follows. First, if the age at which the individual can receive full benefits is missing, it is taken to be 65 , since over $70 \%$ of the individuals who reported such an age reported it to be 65 . Secondly, if the age at which the individual became eligible for early benefits is missing, this age is taken to be 62 (almost half of the individuals who reported such an age reported 62) uniess the age at which he was eligible for full benefits occured earlier. Finally, if the actual 
pension amount is missing, it is imputed according to the regressions reported in Table $A 4 .^{5}$

Social Security. The calculations for the Social Security component of compensation follows much the same approach as that for pensions, except for the fact that the Social Security calculations can reflect the actual rules in greater detail. For the estimation of the model and for the simulations presented in Section $V$, the calculations use the Social Security rules actually in place during the sample period, from 1969 to 1979. The simulations of Section VI are intended to investigate the effects of the recent changes in the Social Security rules and hence use the more recent rules. In both cases, the individual is assumed to consider the effects of Social Security which operate through his spouse's benefits and through her potential widow's benefits as well as through his own benefits.

The rules during the sample period, as reflected in the model, include the following features: (i) the formulae for calculating the average monthly earnings and the primary insurance amount, (ii) the earnings disregard and, prior to 1972, a second earnings break point above which earnings were effectively taxed at $100 \%$, (iii) the reduction of benefits for retirement before age 65 , (iv) automatic benefit recomputation if the individual lost benefits due to the earnings test, and ( $v$ ) the indexing of benefits after an individual had started collecting them. In the average monthly earnings calculations, the individual's actual earnings from the Social Security records are used up to age 55, and after that the earnings implied by the model are used. 6 The percentages used in the primary insurance amount formula, which were adjusted by Congress in an ad hoc manner prior to 1972, are characterized as being adjusted according to 
average hourly earnings throughout the period. 7 And finally, as stressed by Burkhauser and Turner, the benefit reductions for early retirement are assumed to have been fixed in nominal rather than real terms.

For the simulations using the more recent rules, several changes in the simulation procedure are made in addition to using the more recent figures for the normal retirement age, the early retirement penalty percentage, and the delayed retirement credit percentage. First, these calculations use the average indexed monthly earnings formula, and in the averages they use a full 35 years' worth of earnings, not just the years since 1951. This reflects the number of years which will eventually be used for everyone once the system reaches a steady state. Secondly, no maximum is applied to earnings subject to Social Security, which reflects the fact that the present maximum is so large that it applies to only a small fraction of earners but which contrasts with the relatively low maximum amounts in force through the 1950's and 1960's. And finally, reflecting a change in the rules since the sample period, the reductions in benefits due to early retirement are assumed to be adjusted for inflation in these simulations instead of being fixed in nominal terms.

With these rules, it is possible to calculate the discounted value of the Social security benefits if an individual were to retire at a given age, and to calculate the discounted value if the individual were to have retired in the previous year. The Social Security component of compensation is then taken as the difference between the two, which is attributable to the additional year's work. Such calculations are undertaken both for the individual's full-time job and for any amount of work that he may choose in a part-time job.

Total Compensation Profiles. At each age, the compensation for ful1time work is calculated as the sum of the wage, pension, and Social 
Security components. The wage component is in turn calculated as the ful1time wage rate times the average annual hours which the individual reported working in full-time jobs during the survey, or if such an average cannot be computed, times 2000 hours. The compensation for part-time work is calculated as the sum of the wage and Social Security components, with the assumption that pensions do not figure in part-time work. For any given year, the rate of part-time compensation is not a constant amount but, due to the nature of the Social Security system, it depends on the number of part-time hours worked.

A problem which arises from these imputations is that some individuals are observed to have worked full-time when, according to the imputations, it would have been possible to receive more compensation from their parttime jobs. This may arise either from the imputation procedure, particularly for the part-time wage, or by misclassification of the individual as working full-time when in fact he is in a part-time job. The difficulty is that such a choice is not consistent with any combination of the stochastic variables in the model and hence would cause the maximum likelihood estimation procedure to fail. It would be possible to avoid the difficulties by including another stochastic variable related to imputed wages, but an additional stochastic term would most likely increase the computational burden to the point of rendering it infeasible. other potential solutions might cause the estimation procedure to pay undue attention to these observations when in fact it seems that their informational content is almost nil. If an individual says that he is in a full-time job when earnings are less than in a potential part-time job with fewer hours, it is impossible to infer very much of anything about the preferences of the individual. Given that such individuals appear to 
provide no useful information to the estimation procedure, it seems best simply to drop them rather than to attempt some kind of further correction which risks severely distorting the estimates. For this reason 21 of 531 whites in more demanding jobs, 28 of 394 whites in less demanding jobs, 27 of 308 blacks in more demanding jobs, and 15 of 144 blacks in less demanding jobs are excluded from the sample.

The Retirement Sequence. In addition to calculating the compensation profiles for full-time and part-time work, it is necessary for purposes of estimation to specify the retirement sequence for each individual in the sample. The retirement sequence, which is essentially the dependent variable in the estimation, consists of up to six observations for each individual about whether he was completely retired, partially retired, or not retired at a 11 . In almost all instances, the individual's response is taken at face value. The exception is for an individual who reported nimself to be partially retired despite the fact that he had not held a job in the previous two years. Such an individual, for the purposes of the estimation procedure, is considered to be fully retired.

A problem arises with what may be called "reverse" sequences in which an individual reports himself to be working full-time after having been partially or fully retired or reports himself to be partialiy retired after having been fully retired. Such sequences would not in general be predicted by the model for any combination of the stochastic variables and hence would cause the estimation procedure to fail. The most likely cause of reverse sequences would seem to be unforseen changes which either decrease the disutility of working or increase its rewards. There are a couple of approaches which could be used to incorporate uncertainty of this kind into the model, but both have severe drawbacks. Parameter estimates could be derived using the recent "random walk" models of labor supply, but 
this kind of a model is not very useful for analyzing the effects of changes which affect the budget constraint over a significant part of the Tife cycle. Another approach would be to introduce a time-varying stochastic variable in the utility function and/or budget constraint. The difficulty with this approach is basically computational--the introduction of additional stochastic terms in the model would tend to increase the computational burden nearly exponentially and hence render the model impossible to estimate.

Despite the fact that the exact factors causing reversals are not explained in the context of the model, the sequences do contain useful information about the stochastic variables. For example, a sequence which begins with full-time work and ends with full retirement, but with no partial retirement in between, establishes a rough range for the disutility of work and a minimum value for the elasticity of substitution between consumption and leisure, even if there is a reversal at some point. Similarly, a sequence that begins with full-time work, ends with full retirement, and has some partial retirement in the interim, indicates a rough range of the disutility of work and a maximum value for the substitution elasticity regardless of the presence of a reversal. Therefore, recognizing that the model simply does not have sufficient complexity to explain the reversals, but that nevertheless such sequences do place reasonable limits of the stochastic variables for the individual, the approach followed in the estimation procedure is to drop from the retirement sequence the specific observations which create the reversals, but in a manner which always preserves partial retirement observations if they are present. In essence, the strategy is to use the observations in the sequence which contain useful information about the stochastic 
variables (and hence about the parameters being estimated in the model) while ignoring any observations which do not contribute useful information about the stochastic variables and which require explanations beyond the scope of the model. 
1. The hourly earnings figures are taken from the Economic Report of the President, 1981, Table B-36.

2. All of these test statistics are derived from equations in which the tenure and experience terms are unconstrained and in which quadratic experience and tenure terms are added, so that the rejections are not the result of the constraints which were imposed on the reported equations.

3. Tests for differences between equations for more vs. less demanding jobs are only reported for the much larger sample of whites (although a one in five sample of whites is used for estimation and simulation of the model, the full sample is used for estimation of the wage equations). The relatively low number of blacks in the sample made such tests much less powerful for that group.

4. According to a study for the Urban Institute which is based on the BLS Level of Benefits Survey, more than 80 percent of surveyed participants belong to a plan which either ties their benefits to final pay or in which they receive a dollar amount for each year of service (Hatch et a1, 1981, p. 25).

5. Test statistics for different equations for blacks and for whites are 0.78 for more physically demanding jobs, compared to a $5 \%$ critical value of 1.88 , and 0.98 for less demanding jobs, compared to a $5 \%$ critical value of 1.83 . The statistic for differences between more vs. less demanding jobs is 2.14 for whites, which is above the $5 \%$ critical value of 1.83 but below the $1 \%$ critical value of 2.32 .

6. This procedure is followed to insure that the calculations fairly closely reproduce the effect of additional earnings on average monthly earnings while at the same time allowing for the fact that after age 55 , the Social Security earnings records increasingly fail to reflect potential earnings for those who partially or fully retire.

7. This approach does not reflect the unusually large increase in benefits in 1972 , but otherwise it does approximate reasonably well the benefit formulae actually encountered during this period. In particular, it reflects the phenomenon of "double indexing," which was responsible for the large increases in the real value of Social Security benefits during this period. 
Ful1-Time Wage Equations $(R H S)^{a}$

\begin{tabular}{|c|c|c|c|c|}
\hline & $\begin{array}{l}\text { White } \\
\text { MDJ Job }\end{array}$ & $\begin{array}{l}\text { White } \\
\text { LDJ Job }\end{array}$ & $\begin{array}{l}\text { Black } \\
\text { MiDJ Job }\end{array}$ & $\begin{array}{l}\text { B lack } \\
\text { LDJ Job }\end{array}$ \\
\hline Constant & $\begin{array}{c}0.847 \\
(0.044)\end{array}$ & $\begin{array}{l}1.054 \\
(0.100)\end{array}$ & $\begin{array}{l}0.225 \\
(0.110)\end{array}$ & $\begin{array}{c}0.716 \\
(0.181)\end{array}$ \\
\hline Years of Experience ${ }^{b}$ & $\begin{array}{l}-0.006 \\
(0.001)\end{array}$ & $\begin{array}{l}-0.014 \\
(0.001)\end{array}$ & $\begin{array}{l}0.005 \\
(0.002)\end{array}$ & $\begin{array}{l}-0.008 \\
(0.003)\end{array}$ \\
\hline Years of Tenure ${ }^{c}$ & $\begin{array}{c}0.002 \\
(0.001)\end{array}$ & $\begin{array}{c}0.007 \\
(0.001)\end{array}$ & $\begin{array}{c}0.004 \\
(0.002)\end{array}$ & $\begin{array}{l}0.000 \\
(0.003)\end{array}$ \\
\hline Occupation Category $1^{\mathrm{d}}$ & & $\begin{array}{c}0.378 \\
(0.024)\end{array}$ & & $\begin{array}{c}0.287 \\
(0.087)\end{array}$ \\
\hline Occupation Category 2 & & $\begin{array}{l}0.186 \\
(0.025)\end{array}$ & & $\begin{array}{l}0.259 \\
(0.098)\end{array}$ \\
\hline Occupation Category 4 & $\begin{array}{l}0.240 \\
(0.017)\end{array}$ & $\begin{array}{l}0.180 \\
(0.057)\end{array}$ & $\begin{array}{l}-0.192 \\
(0.042)\end{array}$ & $\begin{array}{c}0.197 \\
(0.282)\end{array}$ \\
\hline $\begin{array}{c}\text { Dummy Variable for Private } \\
\text { Pension Eligibility }\end{array}$ & $\begin{array}{l}0.288 \\
(0.014)\end{array}$ & $\begin{array}{c}0.211 \\
(0.020)\end{array}$ & $\begin{array}{c}0.417 \\
(0.049)\end{array}$ & $\begin{array}{l}0.206 \\
(0.081)\end{array}$ \\
\hline $\begin{array}{c}\text { Dummy Variable for Public } \\
\text { Pension Eligibility }\end{array}$ & $\begin{array}{l}0.198 \\
(0.020)\end{array}$ & $\begin{array}{l}0.237 \\
(0.021)\end{array}$ & $\begin{array}{l}0.307 \\
(0.068)\end{array}$ & $\begin{array}{l}0.229 \\
(0.071)\end{array}$ \\
\hline Mandatory Retirement Horizone & $\begin{array}{l}0.006 \\
(0.002)\end{array}$ & $\begin{array}{l}0.007 \\
(0.003)\end{array}$ & $\begin{array}{c}0.014 \\
(0.008)\end{array}$ & $\begin{array}{l}0.024 \\
(0.010)\end{array}$ \\
\hline $\begin{array}{l}\text { Dummy Variable for Short-Term } \\
\text { Health Problem }\end{array}$ & $\begin{array}{l}-0.009 \\
(0.037)\end{array}$ & $\begin{array}{l}-0.028 \\
(0.055)\end{array}$ & $\begin{array}{l}-0.037 \\
(0.112)\end{array}$ & $\begin{array}{l}0.074 \\
(0.165)\end{array}$ \\
\hline $\begin{array}{l}\text { Dummy Variable for Long-Term } \\
\text { Health Problem }\end{array}$ & $\begin{array}{l}-0.044 \\
(0.016)\end{array}$ & $\begin{array}{l}-0.066 \\
(0.022)\end{array}$ & $\begin{array}{l}-0.157 \\
(0.058)\end{array}$ & $\begin{array}{l}-0.040 \\
(0.075)\end{array}$ \\
\hline $\begin{array}{l}\text { Dummy Variable for Health Problem } \\
\text { That Ended the Previous Job }\end{array}$ & $\begin{array}{l}-0.124 \\
(0.039)\end{array}$ & $\begin{array}{l}-0.058 \\
(0.050)\end{array}$ & $\begin{array}{l}-0.120 \\
(0.135)\end{array}$ & $\begin{array}{l}-0.330 \\
(0.151)\end{array}$ \\
\hline $\begin{array}{l}\text { Dummy Variable Equal to Unity If } \\
\text { Father's Occupation Is Nonfarm }\end{array}$ & $\begin{array}{l}0.110 \\
(0.012)\end{array}$ & $\begin{array}{c}0.146 \\
(0.018)\end{array}$ & $\begin{array}{l}0.025 \\
(0.041)\end{array}$ & $\begin{array}{c}0.120 \\
(0.060)\end{array}$ \\
\hline Years of Education & $\begin{array}{l}0.020 \\
(0.005)\end{array}$ & $\begin{array}{l}0.000 \\
(0.013)\end{array}$ & $\begin{array}{l}0.006 \\
(0.012)\end{array}$ & $\begin{array}{l}-0.004 \\
(0.021)\end{array}$ \\
\hline $\begin{array}{l}\text { Years of Education in Excess of } \\
8 \text { Years }\end{array}$ & $\begin{array}{l}0.016 \\
(0.010)\end{array}$ & $\begin{array}{l}0.013 \\
(0.021)\end{array}$ & $\begin{array}{l}0.088 \\
(0.040)\end{array}$ & $\begin{array}{c}0.090 \\
(0.055)\end{array}$ \\
\hline $\begin{array}{l}\text { Years of Education in Excess of } \\
12 \text { Years }\end{array}$ & $\begin{array}{l}-0.027 \\
(0.018)\end{array}$ & $\begin{array}{c}0.007 \\
(0.016)\end{array}$ & $\begin{array}{l}-0.120 \\
(0.074)\end{array}$ & $\begin{array}{l}-0.068 \\
(0.072)\end{array}$ \\
\hline
\end{tabular}


Table Al (continued)

$\begin{array}{llccc}\text { Dummy Variable for High School } & -0.072 & 0.058 & -0.233 & -0.418 \\ \text { School Graduation } & (0.027) & (0.042) & (0.136) & (0.173) \\ \begin{array}{l}\text { Dummy variable for College } \\ \text { Graduation }\end{array} & -0.020 & 0.076 & 0.086 & 0.389 \\ \text { Number of Observations } & (0.084) & (0.047) & (0.375) & (0.257) \\ \mathrm{R}^{2} & 4062 & 3749 & 498 & 308 \\ & 0.33 & 0.44 & 0.29 & 0.41\end{array}$

a. Dependent variable is the log of the hourly wage rate. Standard errors are in parentheses. The regressions include multiple wage observations for some individuals, and the reported standard errors are uncorrected for the possibility that the multiple observations for a single individual may be correlated.

b. Years of experience is calculated as the age less years of education less six.

c. The sum of the experience and tenure variables is constrained in these regressions, as noted in the text.

d. The occupational categories are as follows:

1: Professional and technical workers, farmers, managers, officials, and proprietors.

2: Clerical and sales workers.

3: Craftsmen, foremen, operatives and service workers (this is the omitted group in al1 regressions).

4: Laborers and farm foremen.

e. The mandatory retirement horizon is calculated as ten less the number of years until mandatory retirement if the individual is subject to mandatory retirement and if this number is greater than zero, and zero otherwise. 
Fu11-Time Wage Equations (PSID) ${ }^{\text {a }}$

\begin{tabular}{|c|c|c|c|c|}
\hline & $\begin{array}{l}\text { White } \\
\text { MDJ Job }\end{array}$ & $\begin{array}{l}\text { White } \\
\text { LDJ Job }\end{array}$ & $\begin{array}{l}\text { B lack } \\
\text { MDJ Job }\end{array}$ & $\begin{array}{l}\text { Black } \\
\text { LDJ Job }\end{array}$ \\
\hline Constant & $\begin{array}{c}0.691 \\
(0.155)\end{array}$ & $\begin{array}{l}-0.225 \\
(0.728)\end{array}$ & $\begin{array}{c}0.542 \\
(0.138)\end{array}$ & $\begin{array}{l}-0.677 \\
(0.758)\end{array}$ \\
\hline Years of Experience & $\begin{array}{l}0.008 \\
(0.007)\end{array}$ & $\begin{array}{l}0.029 \\
(0.007)\end{array}$ & $\begin{array}{l}0.007 \\
(0.008)\end{array}$ & $\begin{array}{c}0.000 \\
(0.023)\end{array}$ \\
\hline Square of Experience & $\begin{array}{l}0.00000 \\
(0.00016)\end{array}$ & $\begin{array}{l}-0.00042 \\
(0.00020)\end{array}$ & $\begin{array}{c}0.00002 \\
(0.00017)\end{array}$ & $\begin{array}{c}0.00006 \\
(0.00057)\end{array}$ \\
\hline Years of Tenure & $\begin{array}{l}0.009 \\
(0.006)\end{array}$ & $\begin{array}{l}0.026 \\
(0.007)\end{array}$ & $\begin{array}{c}0.017 \\
(0.007)\end{array}$ & $\begin{array}{c}0.027 \\
(0.024)\end{array}$ \\
\hline Square of Tenure & $\begin{array}{l}-0.00023 \\
(0.00022)\end{array}$ & $\begin{array}{l}-0.00078 \\
(0.00026)\end{array}$ & $\begin{array}{l}-0.00055 \\
(0.00026)\end{array}$ & $\begin{array}{l}-0.00048 \\
(0.00097)\end{array}$ \\
\hline Occupation Category 1 & & $\begin{array}{l}0.099 \\
(0.039)\end{array}$ & & $\begin{array}{l}-0.015 \\
(0.105)\end{array}$ \\
\hline Occupation Category 4 & $\begin{array}{l}-0.268 \\
(0.042)\end{array}$ & $\begin{array}{l}-0.043 \\
(0.060)\end{array}$ & $\begin{array}{l}-0.170 \\
(0.036)\end{array}$ & $\begin{array}{l}-0.099 \\
(0.123)\end{array}$ \\
\hline $\begin{array}{c}\text { Dummy Variable for Private } \\
\text { Pension Eligibility }\end{array}$ & $\begin{array}{c}0.177 \\
(0.031)\end{array}$ & $\begin{array}{c}0.192 \\
(0.038)\end{array}$ & $\begin{array}{l}0.258 \\
(0.038)\end{array}$ & $\begin{array}{c}0.327 \\
(0.123)\end{array}$ \\
\hline $\begin{array}{l}\text { Dummy Variable for Public } \\
\text { Pension Eligibility }\end{array}$ & $\begin{array}{l}0.129 \\
(0.054)\end{array}$ & $\begin{array}{c}0.107 \\
(0.045)\end{array}$ & $\begin{array}{l}0.305 \\
(0.050)\end{array}$ & $\begin{array}{c}0.415 \\
(0.129)\end{array}$ \\
\hline $\begin{array}{l}\text { Dummy Variable for Short-Term } \\
\text { Health Problem }\end{array}$ & $\begin{array}{l}-0.032 \\
(0.103)\end{array}$ & $\begin{array}{l}-0.132 \\
(0.176)\end{array}$ & $\begin{array}{c}0.181 \\
(0.147)\end{array}$ & \\
\hline $\begin{array}{l}\text { Dummy Variable for Long-Term } \\
\text { Health Problem }\end{array}$ & $\begin{array}{l}-0.071 \\
(0.074)\end{array}$ & $\begin{array}{l}0.079 \\
(0.088)\end{array}$ & $\begin{array}{l}-0.163 \\
(0.091)\end{array}$ & $\begin{array}{c}0.225 \\
(0.478)\end{array}$ \\
\hline $\begin{array}{l}\text { Dummy Variable Equal to Unity If } \\
\text { Father's Occupation Is Nonfarm }\end{array}$ & $\begin{array}{l}0.046 \\
(0.033)\end{array}$ & $\begin{array}{l}0.107 \\
(0.046)\end{array}$ & $\begin{array}{c}0.034 \\
(0.036)\end{array}$ & $\begin{array}{c}0.264 \\
(0.121)\end{array}$ \\
\hline Years of Education & $\begin{array}{l}0.051 \\
(0.020)\end{array}$ & $\begin{array}{l}0.116 \\
(0.095)\end{array}$ & $\begin{array}{l}0.047 \\
(0.017)\end{array}$ & $\begin{array}{l}0.202 \\
(0.107)\end{array}$ \\
\hline $\begin{array}{l}\text { Years of Education in Excess of } \\
8 \text { Years }\end{array}$ & $\begin{array}{l}-0.002 \\
(0.033)\end{array}$ & $\begin{array}{l}-0.019 \\
(0.122)\end{array}$ & $\begin{array}{l}-0.041 \\
(0.032)\end{array}$ & $\begin{array}{l}-0.331 \\
(0.165)\end{array}$ \\
\hline $\begin{array}{l}\text { Years of Education in Excess of } \\
12 \text { Years }\end{array}$ & $\begin{array}{l}0.003 \\
(0.032)\end{array}$ & $\begin{array}{l}-0.029 \\
(0.054)\end{array}$ & $\begin{array}{l}-0.015 \\
(0.049)\end{array}$ & $\begin{array}{l}0.185 \\
(0.100)\end{array}$ \\
\hline $\begin{array}{l}\text { Dummy Variable for High School } \\
\text { School Graduation }\end{array}$ & $\begin{array}{l}0.014 \\
(0.062)\end{array}$ & $\begin{array}{l}-0.143 \\
(0.139)\end{array}$ & $\begin{array}{l}0.205 \\
(0.069)\end{array}$ & $\begin{array}{l}0.246 \\
(0.229)\end{array}$ \\
\hline
\end{tabular}


Table A2 (continued)

Dummy variable for College Graduation

Number of Observations

$R^{2}$
$-0.204$

$(0.126)$

610

0.24

0.30

0.015

$-0.093$

0.306

$(0.072)$

$(0.244)$

(0.197)

698

455

120

0.30

0.36

a. See notes to Table A1. All notes to that table apply here, except as follows. First, the sum of tenure and experience is unconstrained in these regressions. Secondly, the PSID lumps service workers and laborers into a single occupational group, and in these regressions service workers are placed in occupational category 4, along with laborers. This treatment leaves no workers in occupational category 3 for LPD jobs, so occupational category 2 is used as the omitted group for the two regressions for LPD jobs. 


\begin{tabular}{|c|c|c|c|c|}
\hline & \multicolumn{2}{|c|}{$\begin{array}{c}\text { Part-Time Jobs } \\
\text { Begun Before } \\
\text { Age } 55\end{array}$} & \multicolumn{2}{|c|}{$\begin{array}{l}\text { Part-Time Jobs } \\
\text { Begun After } \\
\text { Age } 55\end{array}$} \\
\hline & White & B lack & White & Black \\
\hline Constant & $\begin{array}{l}0.096 \\
(0.239)\end{array}$ & $\begin{array}{c}0.342 \\
(0.203)\end{array}$ & $\begin{array}{l}0.100 \\
(0.130)\end{array}$ & $\begin{array}{l}-0.046 \\
(0.149)\end{array}$ \\
\hline 0ccupation Category 1 & $\begin{array}{l}0.363 \\
(0.110)\end{array}$ & $\begin{array}{l}0.606 \\
(0.419)\end{array}$ & & \\
\hline 0ccupation Category 2 & $\begin{array}{c}0.320 \\
(0.099)\end{array}$ & $\begin{array}{c}0.191 \\
(0.305)\end{array}$ & & \\
\hline 0ccupation Category 4 & $\begin{array}{l}-0.006 \\
(0.128)\end{array}$ & $\begin{array}{l}-0.121 \\
(0.141)\end{array}$ & & \\
\hline $\begin{array}{l}\text { Dummy Variable for Private } \\
\text { Pension Eligibility }\end{array}$ & $\begin{array}{c}0.475 \\
(0.102)\end{array}$ & $\begin{array}{l}1.357 \\
(0.378)\end{array}$ & & \\
\hline $\begin{array}{l}\text { Dummy Variable for Public } \\
\text { Pension Eligibility }\end{array}$ & $\begin{array}{c}0.055 \\
(0.213)\end{array}$ & $\begin{array}{c}0.601 \\
(0.310)\end{array}$ & & \\
\hline Mandatory Retirement Horizon & $\begin{array}{c}0.036 \\
(0.016)\end{array}$ & $\begin{array}{l}-0.026 \\
(0.042)\end{array}$ & & \\
\hline $\begin{array}{l}\text { Dummy Variable for Short-Term } \\
\text { Health Problem }\end{array}$ & $\begin{array}{l}-0.120 \\
(0.163)\end{array}$ & $\begin{array}{l}-0.243 \\
(0.472)\end{array}$ & $\begin{array}{l}-0.067 \\
(0.098)\end{array}$ & $\begin{array}{c}0.140 \\
(0.195)\end{array}$ \\
\hline $\begin{array}{l}\text { Dummy Variable for Long-Term } \\
\text { Health Problem }\end{array}$ & $\begin{array}{l}-0.086 \\
(0.083)\end{array}$ & $\begin{array}{l}-0.210 \\
(0.137)\end{array}$ & $\begin{array}{l}-0.034 \\
(0.041)\end{array}$ & $\begin{array}{l}-0.011 \\
(0.102)\end{array}$ \\
\hline $\begin{array}{l}\text { Dummy Variable for Health Problem } \\
\text { That Ended the Previous Job }\end{array}$ & $\begin{array}{c}0.103 \\
(0.185)\end{array}$ & $\begin{array}{l}0.153 \\
(0.238)\end{array}$ & $\begin{array}{l}-0.141 \\
(0.059)\end{array}$ & $\begin{array}{l}-0.208 \\
(0.127)\end{array}$ \\
\hline $\begin{array}{l}\text { Dummy Variable Equal to Unity If } \\
\text { Father's Occupation Is Nonfarm }\end{array}$ & $\begin{array}{c}0.152 \\
(0.081)\end{array}$ & $\begin{array}{l}-0.298 \\
(0.136)\end{array}$ & $\begin{array}{c}0.152 \\
(0.036)\end{array}$ & $\begin{array}{l}-0.078 \\
(0.098)\end{array}$ \\
\hline Years of Education & $\begin{array}{c}0.026 \\
(0.032)\end{array}$ & $\begin{array}{c}0.001 \\
(0.035)\end{array}$ & $\begin{array}{c}0.025 \\
(0.017)\end{array}$ & $\begin{array}{c}0.041 \\
(0.027)\end{array}$ \\
\hline $\begin{array}{l}\text { Years of Education in Excess of } \\
8 \text { Years }\end{array}$ & $\begin{array}{c}0.002 \\
(0.068)\end{array}$ & $\begin{array}{l}-0.058 \\
(0.139)\end{array}$ & $\begin{array}{c}0.040 \\
(0.032)\end{array}$ & $\begin{array}{c}0.028 \\
(0.088)\end{array}$ \\
\hline $\begin{array}{l}\text { Years of Education in Excess of } \\
12 \text { Years }\end{array}$ & $\begin{array}{c}0.125 \\
(0.087)\end{array}$ & $\begin{array}{c}0.198 \\
(0.237)\end{array}$ & $\begin{array}{l}0.005 \\
(0.038)\end{array}$ & $\begin{array}{l}-0.170 \\
(0.127)\end{array}$ \\
\hline $\begin{array}{l}\text { Dummy Variable for High School } \\
\text { School Graduation }\end{array}$ & $\begin{array}{c}0.039 \\
(0.184)\end{array}$ & $\begin{array}{c}0.373 \\
(0.519)\end{array}$ & $\begin{array}{l}-0.121 \\
(0.084)\end{array}$ & $\begin{array}{l}-0.043 \\
(0.267)\end{array}$ \\
\hline
\end{tabular}


Table A3 (continued)

Dummy variable for College Graduation

Number of Observations

$R^{2}$

a. See notes to Table Al. $\begin{array}{llll}-0.394 & -0.292 & -0.011 & 0.619\end{array}$

$\begin{array}{llll}(0.314) & (0.929) & (0.144) & (0.520)\end{array}$

$\begin{array}{llll}403 & 64 & 1210 & 118\end{array}$

$\begin{array}{llll}0.27 & 0.50 & 0.10 & 0.14\end{array}$ 


\begin{tabular}{|c|c|c|c|c|}
\hline & \multicolumn{2}{|c|}{$\begin{array}{l}\text { With Industry } \\
\text { and occupation }\end{array}$} & \multicolumn{2}{|c|}{$\begin{array}{l}\text { Without Industry } \\
\text { and Occupation }\end{array}$} \\
\hline & MDJ Job & LDJ Job & MDJ Job & LDJ Job \\
\hline Constant & $\begin{array}{l}3.969 \\
(0.116)\end{array}$ & $\begin{array}{l}3.922 \\
(0.147)\end{array}$ & $\begin{array}{c}4.143 \\
(0.112)\end{array}$ & $\begin{array}{c}4.460 \\
(0.115)\end{array}$ \\
\hline Log of Hourly Wage & $\begin{array}{c}0.350 \\
(0.089)\end{array}$ & $\begin{array}{c}0.150 \\
(0.086)\end{array}$ & $\begin{array}{c}0.404 \\
(0.090)\end{array}$ & $\begin{array}{c}0.278 \\
(0.079)\end{array}$ \\
\hline Occupation Category 1 & & $\begin{array}{l}0.515 \\
(0.122)\end{array}$ & & \\
\hline Occupation Category 2 & & $\begin{array}{c}0.202 \\
(0.130)\end{array}$ & & \\
\hline Occupation Category 4 & $\begin{array}{l}0.195 \\
(0.122)\end{array}$ & $\begin{array}{c}0.002 \\
(0.346)\end{array}$ & & \\
\hline Industry 1 & $\begin{array}{c}0.887 \\
(0.707)\end{array}$ & $\begin{array}{c}0.195 \\
(0.685)\end{array}$ & & \\
\hline Industry 2 & $\begin{array}{c}0.688 \\
(0.211)\end{array}$ & $\begin{array}{c}0.018 \\
(0.453)\end{array}$ & & \\
\hline Industry 3 & $\begin{array}{c}0.991 \\
(0.121)\end{array}$ & $\begin{array}{c}0.487 \\
(0.238)\end{array}$ & & \\
\hline Industry 5 & $\begin{array}{c}0.053 \\
(0.124)\end{array}$ & $\begin{array}{c}0.039 \\
(0.156)\end{array}$ & & \\
\hline Industry 6 & $\begin{array}{c}0.231 \\
(0.171)\end{array}$ & $\begin{array}{c}0.150 \\
(0.163)\end{array}$ & & \\
\hline Industry 7 & $\begin{array}{l}0.200 \\
(0.189)\end{array}$ & $\begin{array}{c}0.566 \\
(0.109)\end{array}$ & & \\
\hline Industry 8 & $\begin{array}{c}0.573 \\
(0.161)\end{array}$ & $\begin{array}{c}0.791 \\
(0.119)\end{array}$ & & \\
\hline Number of Observations & 1041 & 845 & 1041 & 845 \\
\hline $\mathrm{R}^{2}$ & 0.10 & 0.10 & 0.02 & 0.01 \\
\hline
\end{tabular}

a. Dependent variable is log(annual pension amount/tenura). The occupation categories are the same as in the footnotes to Table A1. The industry categories are as follows: 
Footnotes to Table A4 (continued)

1: Agriculture, forestry and fisheries.

2: Mining.

3: Construction.

4: Manufacturing.

5: Transportation, communication and public utilities.

6: Wholesale and retail trade.

7: Finance, insurance and real estate, business and repair services, personal services, entertainment and recreation, professional and related services.

8: Public administration. 